ÉGYPTE monde arabe

\section{Égypte/Monde arabe}

13 | 2015

Nouvelles luttes autour du genre en Egypte depuis 2011

\title{
El-Sissi's Women? Shifting gender discourses and the limits of state feminism
}

Les « femmes de Sissi »? Mutations des discours du genre et limites du féminisme d'État

Hind Ahmed Zaki

\section{(2) OpenEdition}

Journals

Electronic version

URL: https://journals.openedition.org/ema/3503

DOI: $10.4000 /$ ema.3503

ISSN: 2090-7273

Translation(s):

Les «femmes de Sissi »? Mutations des discours du genre et limites du féminisme d'État - URL :

https://journals.openedition.org/ema/3510 [fr]

\section{Publisher}

CEDEJ - Centre d'études et de documentation économiques juridiques et sociales

\section{Printed version}

Date of publication: 10 November 2015

Number of pages: $39-53$

ISBN: 9782905838865

ISSN: 1110-5097

Electronic reference

Hind Ahmed Zaki, "El-Sissi's Women? Shifting gender discourses and the limits of state feminism", Égypte/Monde arabe [Online], 13 | 2015, Online since 10 November 2017, connection on 07 July 2022. URL: http://journals.openedition.org/ema/3503 ; DOI: https://doi.org/10.4000/ema.3503 


\section{Hind Ahmed Zaki}

\section{EL-SISSI'S WOMEN? \\ SHIFTING GENDER DISCOURSES AND \\ THE LIMITS OF STATE FEMINISM}

\section{ABSTRACT}

In the wake of the overthrow of former President Morsi amid massive demonstrations through June and July 2013, a specific new gender discourse began emerging in Egypt. Focusing on the high levels of participation of women from all wakes of life in the demonstrations against Islamist rule in Egypt, this new popular discourse is articulated in vernacular forms of expression, in the media, or in the writings of intellectuals and political analysts. It stresses the supposedly unanimous and uncontested support of "Egyptian women" as a uniform category, to the Egyptian military in their war against Islamic terrorism and to the military State, as well as their purportedly universal infatuation with President Abd El-Fattah El-Sissi. This indicates the rise of a new discursive form of State feminism, one that seeks to erase a rich four-year history of diverse gender-based mobilization.

This article deconstructs the myth of "El-Sissi's women" in reference to particular models of gendered imaginations of the nation-State and Egyptian women in the twentieth century, as well as their political expressions - and to the emerging "revolutionary" representation of women since 2011. These images and narratives allow us to decode the media-borne myth of "El-Sissi's women" and analyze it as an attempt to construct a new and disturbing discursive form of State feminism. The politicization of women's images - dancing in front of ballot boxes in the 2014 presidential elections or expressing support for their favorite candidate El-Sissi in videos - is part of this emerging discursive attempt to mask the multitude of claims women address to the State and of readings of women's rights. By constructing the image of "Egyptian women" as a unified category and silencing alternative and independent voices, this new State feminism instrumentalizes 
women and their issues for political purposes in this period of sharp political and identity-based polarization, while giving them little in return.

\section{INTRODUCTION}

On the eve of Egypt's 2014 presidential election, queues of voters stood patiently under May's burning sun, waiting to cast their votes. Among those waiting, the high presence of women was quite remarkable and remarked upon. ${ }^{1}$ During the first day of the election, videos of Egyptian women from all walks of life dancing in celebration at the polls circulated widely on social media. ${ }^{2}$

Such expressions of support came as the last in a series of media portrayals designed to evoke the "gendered" factor in the June 30th revolution/coup. Women's supposed infatuation with the military-backed candidate, Abd El-Fattah El-Sissi was repeatedly commented on, and slightly made fun of, by local and international media. Such images of women's jubilation came at a time when the idea that women played a massive role in toppling the rule of Muslim Brotherhood was gaining a great deal of ground.

Less than a fortnight later, a video of a woman being sexually assaulted by a group of men at the inaugural celebrations for Egypt's new President, surfaced online. Graphic footage, apparently filmed using a mobile phone, shows a mob of men surrounding the young woman, who was stripped of her clothes and badly bruised. The video circulated widely on social media websites. ${ }^{3}$ While women's rights activists had been regularly reporting such brutal attacks against women in the public sphere since 2012, this was the first time the state took real measures to deal with such crimes. Seven arrests were made in relation to the incident. ${ }^{4}$ Moreover, Egypt's new president Abd El-Fattah El-Sissi visited one of the survivors of the harrowing attacks, presented her with a large bouquet of flowers, and apologized to her in person. ${ }^{5}$

1. For examples of such coverage see: The Washington Post report by Eric Cunningham: "In Egypt, presidential contender Abdel Fatah al-Sissi appeals to women voters" at http:// www.washingtonpost.com/world/in-egypt-presidential-contender-abdel-fattah-al-sissiappeals-to-women-voters/2014/05/25/eb880eb0-99cd-44d9-ac0e-98e077d2ff33 story.html and the Tahrir Institute for Middle East Policy's report by Sara Abdel Rahim: Sissi, the candidate for Egyptian women? At http://timep.org/commentary/sisi-candidatefor-egyptian-women.

2. For examples of such videos, please see the following links: https://www.youtube. $\mathrm{com} /$ watch? $\mathrm{v}=$ wlfVyq5Y ek, https://www.youtube.com/watch?v=yEL8kz4EiUU, https:// www.youtube.com/watch? $\mathrm{v}=\mathrm{gkM}$ 6C52gl-w.

3. For more details of the incident see: Egypt's Sissi faces challenge over 'sexual terror', The Times of Israel: http://www.timesofisrael.com/egypts-sisi-faces-challenge-oversexual-terror.

4. For more details on the events of the inauguration on June the 8th 2014 see: Patrick Kingsley "Seven arrested for sexually assaulting student during Tahrir Celebrations: http://www.theguardian.com/world/2014/jun/09/seven-arrest-sexual-assault-studenttahrir-square-sisi-inauguration.

5. For details about El-Sissi's visit and the reactions to it, see Mada Masr's report: http://www.madamasr.com/content/sisi-visits-tahrir-square-mob-sexual-assault-victimhospital. 
These two strikingly opposed images of women celebrated, venerated, and then sexually violated in the midst of national celebrations, point to an important question that lies at the heart of any discussion on women and the state in Egypt: What are the limits of state feminism in a time when debates on women's presence and roles in the public sphere seem to echo wider political debates centering on Egypt's identity and future? The answer to this question is far from simple. Apprehending the limits of state feminism in Egypt requires a historical and political understanding of the project itself. It also requires comprehension of the lopsided nature of the process of modernizing the postcolonial Egyptian state. While national imaginations of Egypt as a woman and of the nation as a family have been a constant staple of Egyptian nationalism since the late nineteenth century, this same nationalism rested on gendered assumptions that are far from simple. ${ }^{6}$ In this article, I will attempt to unpack those gendered assumptions, and demonstrate how those imaginings and their political manifestations, have developed in the period following the Arab spring. I will argue that this post-June 30th, 2013 edition of gendered nationalist discourse is nevertheless unique in many ways, rendering it a new and problematic edition of Egyptian state feminism. While it assumes many of the characteristic of earlier statist discourses on women in Egypt, mainly their centering on identity debates, this new state feminism is more grounded in concrete political realities. Furthermore, it is shaped by different strands of women's mobilization, some of which are radically opposed to historically constructed notions of the proper place of women in the nation. However, this new type of state feminism is problematic on a number of fronts, and has become increasingly so following Egypt's June 30th, 2013 coup, as I will explain.

Contradictory understandings of women's presence in the public arena emerged following the 2011 uprising. On the one hand, the politicization of women's bodies, a result of both the revolutionary and the anti-revolutionary waves of mobilization that have swept the country over the past four years, highlights the instrumental use of women as political symbols. On the other hand, the active and increased participation of women in all the events of the past turbulent three years suggests the emergence of a different type of agency, accompanied by several alternative gender discourses in Egypt. The eruption of the issue of violence against women stands out in particular here. While this could be partly explained by an actual increase in the intensity and level of violence against women, it could also be traced to the emergence of an active consciousness among women regarding the extent of the problem, as well as a willingness on their part to do something about it. Thus, both the discursive and the practical parameters of the debate on women's bodies in the public space have significantly departed from the hitherto-accepted categories of meaning and action that

6. Baron: 2005. 
it had long occupied. This in turn, has paved the way for the emergence of a plethora of gendered frames and symbols that defy easy categorization.

In this article, I attempt to unpack these different old and new discourses on women by analyzing in depth the media discourse on women's unanimous support for military rule as the only alternative to the Islamic rule that was bound to decrease the scope of rights enjoyed by Egyptian women. In order to achieve that, I attempt to deconstruct the myth of "El-Sissi's women" through analyzing images of women as political actors in the media. I argue that the politicization of the images of women, dancing in front of polling stations in the last presidential election, or going on record to express their support for El-Sissi as their favorite presidential candidate, represents an attempt to construct a new discursive form of state feminism, one that utilizes women and their issues to serve political purposes while giving them little in return. But this discourse itself is far from simple. On the contrary, I will argue that women's support for El-Sissi represents multiple claims and understandings of women's rights, as well as different strategic claims on the state at a time when the battle over the cultural meanings of women's rights acquires broader political significance in the midst of the unprecedented political polarization that characterizes Egypt's failed democratic transition.

This article is divided into three main parts. In the first, I analyze what I identify as the historical predicament of state feminism in Egypt, and how the latest developments fit into this analysis. In the second part, I outline how the gendered discourses and practices of both the nationalist statist project, and the Islamic project sought to utilize women as political symbols. This, in turn, has led to the constant framing of debates on women in Egypt in terms of identity politics and discussions of authenticity. I further elaborate on this point by critically analyzing the media portrayals of two distinct but interrelated phenomena: the women who publically supported El-Sissi's candidacy and his rise to power following June 30th, 2013 and the popular assumption that Egyptian women en masse are in support of his leadership. By representing those images of supposedly authentic Egyptian women in action, and by juxtaposing them with the Islamists' notions of Egyptian womanhood as culturally authentic, I aim to show the extent to which discussions of women's status on a national level tend to be trapped in an identity debate that avoids the political side of the issue, and aims to prevent constructive debates on the real conditions of women in Egypt. Finally, I conclude with a discussion of the reasons behind the rise of El-Sissi's women as a phenomenon and how this relates to other competing discourses on women's rights in contemporary Egypt.

\section{STATE FEMINISM IN EGYPT: ROOTS AND REALITIES}

In her book Revolutionary Womanhood: Feminisms, Modernity and the state in Nassser's Egypt, historian Laura Bier argues that the gendered and political 
orders that were put in place by the governing elites in the period following nominal independence from Britain in 1923, underwent major changes in the wake of the 1952 coup d'état. ${ }^{7}$ While the newly-established regime in Egypt owed many of its ideas on wider social reforms to earlier social engineering attempts begun in the 1920s and 1930s, it signaled a new beginning on several important fronts. First, instead of merely relying on charitable initiatives by the upper class, the language of social reform entered the phase of scientific planning by a strong central government. ${ }^{8}$ This development paved the way for the state's monopoly over important social issues, both discursively and institutionally, including the women's question.

Second, the discursive and ideological foundations of what later became the Nasserist state came to be closely tied to a clear demarcation of the public and private domains. More importantly, the new state feminism effectively sought to silence a vibrant and rich debate on the women's question that had taken place in the interwar period. This debate shows that different ideals of national womanhood existed and were in competition. ${ }^{9}$ While discussions in the 1920s, until the 1950s, centered on how increased opportunities for work and education for women would influence their traditional roles as caretakers, mothers and housewives, and on how such changes would affect the laws governing intimate relations between men and women within the marriage institution, a different discourse arose from the 1960's onward. This new discourse was centered mostly on women's roles as employed workers and as citizens in a new type of public space. Issues like marriage, divorce and custody of children were regulated and reformed only in a piecemeal manner by the state, and debates on women's status in the private realm became almost nonexistent. ${ }^{10}$ One important indicator of this can be found in the fact that not a single attempt to reform Egypt's personal status laws was made in the 1950s or 1960s. In fact no such attempt was made until 1979, when ill-fated law number 44/1979, popularly known as "Jihan's law", was ruled unconstitutional by Egypt's Supreme Constitutional Court. ${ }^{11}$ Egypt's rulers from Nasser to Sadat, to Mubarak simply shied away from directly addressing the stark gender inequality codified in Egypt's personal status laws, which date back to the 1920s. ${ }^{12}$ These conflicting tendencies have resulted in the current contradictory situation in which Egyptian

\footnotetext{
7. Bier: 2011, p. 37.
}

8. For more on this argument and on critiques of centralized planning see: Bier: 2011 and Mitchell: 1991.

9. El-Shakry, Omnia.2007. The Great Social Laboratory: Subjects of Knowledge in Colonial and Postcolonial Egypt. Stanford, CA: Stanford University Press.

10. Badran, Margot. 2009. Feminism in Islam: Secular and Religious Convergences. Oxford: One world Publications, Baron, Beth. 2005. Egypt As A Woman: Nationalism, Gender and Politics. Berkeley: University of California Press, and Kholoussy, Hanan.2010. For Better, For Worse: The Marriage Crisis That Made Modern Egypt. Stanford: Stanford University Press, and Bier, Laura.2011. Revolutionary Womanhood: Feminisms, Modernity and the State in Nasser's Egypt. Stanford: Stanford University Press.

11. Bier: 2011.

12. Kholoussy: 2010. 
women find themselves to this day: while official state discourse encourages - at least theoretically - the attainment of more public rights (to education, work, and political participation), women are still confronted with serious forms of gender inequality within the private domain of the home and family.

This legacy, a product of Nasser's state and reproduced in slightly different forms during the presidencies of Sadat and Mubarak, has had far-reaching consequences. The private sphere remains an uncontested stronghold of patriarchy. Furthermore, while the state's propaganda has continued to emphasize the role played by women in the workplace, nevertheless, it has always sought to stress that a woman's place is first and foremost at home. This fact was enshrined in Egypt's 1971 Constitution, particularly in article eleven that read as follows:

"The State shall guarantee harmonization between the duties of woman towards the family and her work in the society, ensuring her equality status with man in fields of political, social, cultural and economic life without violation of the rules of Islamic jurisprudence" ${ }^{13}$

Article eleven deserves special attention because it perfectly sums up the contradictions inherent in the state's feminist project in Egypt. The fact that the constitution emphasizes a woman's duties towards her family, as well as the state's role in helping women to reconcile this duty with her role in the public sphere, proves that the state's vision of feminism is deeply influenced by a belief in the sanctity of the family, and in women's traditional roles in it according to certain interpretations of Islamic Shari'a. Significantly, the same constitutional text appeared again in article ten of the short-lived 2012 constitution, and yet again as article eleven in the current 2014 constitution. ${ }^{14}$ One important difference in the 2014 edition is the recognition of the state's responsibility to end all forms of violence against women. However, it remains unclear how this relates to the reconciliation of women's duties in the public and private spheres, and what kind of measures the state will actually implement to ensure that.

The above account of the history of state feminism in Egypt highlights three important aspects. First, state feminist solutions to the problem of how best to ensure the incorporation of women into public life has led to a new envisioning of the home (private), and of the workplace and the street (public), as gendered spaces. Second, these new imaginings, as expressed in official government discourse, were often contradictory, as they sought to balance gender relations without actually confronting the root causes of gender inequality in the private sphere of the home. Third, as a consequence of the previous two aspects, this unresolved contradiction has led to the rise of a social discourse,

13. Egypt's 1971 Constitution, article 11.

14. Egypt's 2012 Constitution, article 10 and Egypt's 2014 Constitution, article 11. 
often sanctioned by the state, on how women should behave once they find themselves crossing the boundaries between the private and the public. These have included prescriptions on the ways women should carry themselves, how they should deal with men, and what they should wear. ${ }^{15}$ The idea that the public space was gendered, and that it was male, became the dominant logic advocated by society and uncontested by the state. This marked Egyptian state feminism as an enigma, for it empowered women to enter public space, yet did not provide the necessary conditions under which their presence could eventually lead to substantive improvements in their status.

\section{NATIONALIST VERSUS ISLAMIC WOMEN: IDENTITY WARS}

One important point of contention between those supporting the July 3rd, 2013 coup, and those against it, centers on the position of women and how Egypt's short-lived Islamist government under President Mohamed Morsi, sought to roll back the legal gains that Egyptian women had made in the past decades. Supporters of the July 3rd coup often singled out women (along with Egypt's Coptic minority) as groups that stood to lose most if the Islamists remained in power. The actions undertaken by the Muslim Brotherhood-led government seemed to lend strength to this argument. The 2012 constitution lacked any mention of gender equality, referring vaguely instead to "equality and equal opportunities for all citizens, men and women." ${ }^{16}$ While this was seen by some as implicitly referring to legal equality between the sexes, many women's rights advocates saw it as the worst Constitution in Egypt's history regarding gender quality, since it was literally silent on the issue. Public debates on the 2012 Constitution and whether it represented a continuation or a break from earlier constitutional traditions in Egypt, echoed earlier debates on women's status stretching all the way back from the 1920s and 1930s. According to historians writing on this topic, debates on state feminism in Egypt culminated in a conservative approach to the question of women's presence in the public space, and in a continuous avoidance of the thorny issue of the state's responsibility in promoting gender equality in the private sphere.

But parallel to this project, there emerged another one; that of turning the gender question into a nationalist one. This was achieved through the dual tactic of promoting one model of womanhood as ideal, and by representing the nation itself as a woman. In her book, Egypt as Woman: Nationalism, Gender and Politics, Beth Baron discusses at length the historically rich process through which Egyptians, influenced by Western nationalist traditions,

15. For more on the origins of state feminism in Egypt under Nasser, see: Bier, Laura. 2011. Revolutionary Womanhood: Feminisms, Modernity and the State in Nasser's Egypt. Stanford: Stanford University Press.

16. Egypt 2012 Constitution, preamble. 
portrayed Egypt as a woman in national iconography, vernacular language and popular culture. ${ }^{17}$ The genealogy of such representations tying women to the state, while not exclusive to Egypt, seems to stretch continuously from the 1920s until the 25th of January, 2011 and the 30th of June, 2013 revolutions. References to Egypt as "Bahya" (a woman's name meaning the beautiful one ) and "Omm El Donia" ("mother of the world") denote an ongoing fascination with the image of Egypt as a woman.

This particular model of ideal Egyptian womanhood, closely tied to representations of the nation itself as a woman, arose in opposition to the two contrasting, Islamist and conservative models. The latter two, that reflect opposing visions of the nation and its women, along with the national model of womanhood explained above, continue to influence the parameters of national discourse on women's status, as well as its limits.

The first model is the one promoted by the Islamists. It is based on an ideal of womanhood as ascribed by the tenets of Islamic Shari' a. While the logic of state feminism in Egypt rests on a public/private duality that values women's participation in public life on the one hand, and stresses their central role as mothers and wives on the other, imaginings of ideal womanhood inspired by the Islamic revival in Egypt are focused on a rejection of the logic of equality itself as a foreign element of Western origin. ${ }^{18}$ While such attitudes toward gender equality date back to the early writings of Muslim Brotherhood leaders and ideologues, they were very much still alive and a part of recent debates following the election of Mohamed Morsi as President in 2012. One incident that highlighted this clearly was the statement issued by the Muslim Brotherhood in early 2013, in response to a declaration by the General Assembly of the United Nations, on violence against women. ${ }^{19}$ Muslim Brotherhood members expressed objections to this statement that formally laid out their views on women's rights for the first time since their ascent to power in June 2012. They included a rejection of the idea of partnership between men and women, advocating instead the Islamic notion of "guardianship" of men over women. Furthermore, the statement mentioned that wives have no right to file legal charges against their husbands for rape, and that husbands should not be subject to the punishments meted out for the rape of a stranger. This statement proved to many that the Muslim Brotherhood's stance on women had remained more or less the same as in the past, despite previous allegations by some of its members that $\mathrm{MB}$ views had changed. ${ }^{20}$

17. Baron,Beth. 2005. Egypt As A Woman: Nationalism, Gender and Politics. Berkeley: University of California Press.

18 Mahmoud, Sabaa. 2004. Politics of Piety: The Islamic Revival and the Feminist Subject. Princeton: Princeton University Press.

19. For the full text of this declaration see: http://www.un.org/womenwatch/daw/csw/ Csw57/CSW57_Agreed_Conclusions \%28CSW_report_excerpt\%29.pdf.

20. For more on the Muslim Brotherhood statement on the UN declaration on violence against women, see: http://www.ikhwanweb.com/article.php?id=30731. 
The second new model is more recent, and is yet to be fully articulated. But it has already informed and inspireed the more recent forms of women's mobilization that have taken place in the past four years since the January 25th, 2011 revolution. This new imagery, while similar to that of the ideal nationalist model of Egyptian womanhood articulated above, nevertheless attempts to push the boundaries of women's participation to the fullest, and in the process, manages to question the very paradigm of the nationalist gender discourse. One important way this is done is through an active engagement in the issue of women's bodies in public space. Such an engagement, while breaking a long-standing taboo on the growing problem of sexual violence in the public sphere, has managed to destabilize the iconic model of national womanhood, and its claims on public space in particular. The challenge presented by such a new wave of "revolutionary feminism" to the older, deeply rooted gender discourses in Egypt has been far from simple. While this challenge seems to be waning now, it has left its mark on the dominant discourses on women in the public sphere in a number of interesting ways. I shall return to this issue in the concluding section.

\section{EL-SISSI'S WOMEN: FALSE GENERALIZATIONS?}

Egypt's two uprisings (January 25th, 2011 and June 30th, 2013) threw into sharp relief all the dynamics summarized above. The official gender discourse of the state came under attack following the overthrow of Mubarak. State feminism, relegated in the popular imagination to the personality cult surrounding Suzanne Mubarak, was vilified as being elitist and far removed from the real occupations of Egyptian women. This continued to be the case under the short-lived government of Morsi, where an anti-feminist discourse prevailed and extended beyond the NCW and state feminism to independent forms of mobilization. The Muslim Brotherhood's attack on women's rights was integral to their new vision of the state and society, and part of a wider campaign to take over the state's institutions.

As a result of the Brotherhood's campaign against women's rights, a new popular discourse articulating the resilience of women in the face of increasing attempts by the Brotherhood to restrict their rights, began to rise. In the lead-up to June 30th, 2013, the media in Egypt began to continuously attack what they perceived as the threat against women coming from the $M B$, and celebrate the resistance of Egyptian women to this adversary. This discourse began to gain momentum in the midst of the mobilization efforts against Muslim Brotherhood rule.

Normative visions of women's liberation from Islamic rule, a discursive logic that was only prevalent among secularly-inclined intellectuals, has become more popular and tied to hegemonic visions of state control, which in effect denotes military control. What is questionable about this new gender 
discourse is the extent to which such support is real or manufactured, or both. An answer to this can be distilled from analyzing and comparing two distinct but interrelated phenomena: the discourse of women who publically supported El-Sissi's candidacy and his rise to power following June 30th, 2013, as well as the more general assumption that Egyptian women en masse support his leadership, much more than men. While these two aspects promoted by popular media are not the same, they nevertheless feed into a common broader narrative on gender in post-June 30th Egypt.

A number of questions arise here: Who are El-Sissi's women? And to what extent do the media representations of those women reflect the real reasons behind their own choices in aligning with the military against the Muslim Brotherhood? Or have their experiences been reconfigured and reproduced in a hegemonic discourse that is politically motivated? Understanding the phenomena of El-Sissi's women requires a critical examination of who these women are, and the reasons why they are being represented as the quintessential Egyptian women. It also requires analysis of how the state-controlled media, as part of its propaganda against Muslim brotherhood rule, incorporated women in a hegemonic discourse seeking to recreate what could be termed a "new hegemonic interpretation of women's lived experiences" ${ }^{21}$

The emergence of the collective figure of Egyptian women unanimously supporting the military in the run-up to June 30th, 2013, involved images of women from all classes and areas of Egypt. The idea of presenting women from all walks of life, seemingly united in their view of the dangers that the Muslim Brotherhood represented to all women in Egypt, began to appear as a common feature of both televised and online media outlets. The diversity of those women's experiences and the different reasons why they might have chosen to side with the military were intentionally blurred.

In the months preceding June 30th, a particular type of women became advocates of this view. This set of women represented a familiar type: those who stood to lose the most from the dismantling of the model of state feminism that existed under Mubarak. Tahani El Gebali, serving as a Supreme Constitutional Court judge, was one of the best-known figures of this group. A regular guest in the media at the time, and an articulate speaker, El Gebali provided the necessary legal and political cover for constructing a hegemonic discourse on why the Brotherhood's rule was bad for women. In addition, figures like El Gebali managed to link gendered critiques of the Brotherhood to visions of a promised authoritarian rule that would save the day by restoring Egypt's own version of modernity, complete with the public/private division of gender roles, against another threatening gender regime promoted by the Islamists. Invoking the Nasserist era's promise of women's liberation as part and parcel of the nation's

21. Rofel, Lisa. 1999. Other Modernities: Gendered Yearnings in China After Socialism. Berkeley: University of California Press. 
liberation from Islamic rule, figures like El Gebali created a discourse focused on the need to return to the state's legacy of protective feminism. ${ }^{22}$ These arguments were mostly constructed around the dangers inherent in the 2012 Constitution, how it failed women, and why women needed to mobilize en masse against it.

Other independent female figures, leftists or Nasserists, who also envisioned Islamic rule as the major threat facing women in Egypt, joined state feminists in their support for the military, albeit less explicitly. One such figure is Shahinda Maklad, a veteran activist for peasant rights, and a product of the Nasserist era's state feminism and the new opportunities for education that it opened to women. Maklad became a central figure of in a drama of contesting gender discourses. During a demonstration against President Morsi in the area around the presidential palace in November 2012, Maklad was attacked by a male member of the MB's Freedom and Justice party who, symbolically enough, put his hand over her mouth to silence her chanting. The video of the incident went viral and constituted a galvanizing tool to mobilize Egyptians against the rule of the Muslim Brotherhood in the months that followed. ${ }^{23}$ Maklad was later interviewed by numerous T.V. channels, further giving voice to a new discourse of gendered opposition to the rule of the Muslim Brotherhood.

But El-Sissi's women are not only state feminists or notable female public figures. Those portrayed by the media as El-Sissi's women also come from more common lower-class backgrounds and have only been made famous by virtue of their praise of the leader.

Some of those women have become celebrities overnight for vilifying the Muslim Brotherhood online. Countless videos of simple Egyptian women speaking about El-Sissi's virility, strength and his other admirable masculine traits, began circulating in the period following the 2013 coup. ${ }^{24}$ While popular discussions of El-Sissi's female supporters have seemed to center specifically on his "masculine appeal", one dimension that has seemed missing from this debate is the extent of many Egyptian women's sense of vulnerability following the increased wave of sexual violence in Egypt in the past three years. One recurrent reason often put forward by women from all walks of life for their support to El-Sissi seems to hinge on the revival of the protective role of the state in relation to women. As mentioned in the first section, state feminist solutions to the problem of how best to ensure the incorporation of women into public life had more recently failed in providing women with a safe public space. This had left women grappling with a paradox that remains true to this day: the public sphere might be the only space where women feel that they have any chance of

22. For more on El-Gibali critiques of Egypt's 2012 constitution, see: CBS's report on January 8th 2013: http://www.cbc.ca/news/world/former-top-court-judge-challengesegypt-s-new-constitution-1.1390698.

23. For the video of Shahinda Makled's incident and an interview with her: https:// www.youtube.com/watch? $=$ U-MsqcaH9UA.

24. For a detailed discussion on El-Sissi's masculine appeal to women: http://www. madamasr.com/content/sisi-and-his-women. 
realizing equality. Since gender inequality in the private space remains uncontested, women's participation in the public sphere, through paid work and political participation at all levels, remains the only sphere of gender contestation in Egypt. To many ordinary Egyptian women from all walks of life, remaining part of public space continues to be the goal of mainstream feminism, just as it was during the Nasserist era. This logic, albeit less emphasized by hegemonic media discussions of El-Sissi's women, was nevertheless expressed both explicitly and implicitly by many of those women. ${ }^{25}$

These larger groups of women who have found El-Sissi appealing as a protector are also able to legitimately express those views, mainly because of the deep-seated conservative discourse of this new brand of state feminism. In this sense, this new gendered discourse does not depart much from the contradictions of earlier state feminist projects in Egypt. On the other hand, notable public female figures like El-Gebali, Maklad and others who have chosen to support El-Sissi might have different motives than common women. For state feminists, support from the state, even if it is only nominal, remains their only viable option given the attacks on their very existence following January 25th, 2011. However, it remains clear that women's support for military rule and for El-Sissi is neither a universal phenomenon, nor is it motivated by the same reasons or guided by the same logic. On the contrary, El-Sissi's women represent diverse individual subjectivities and conflicting constituencies that express numerous, competing gender discourses. Moreover, they also represent only one of many emerging gender discourses that might actually depart significantly from both the historical model of state feminism in Egypt, and its two alternatives: Islamic feminism and revolutionary feminism.

\section{CONCLUSION}

In Egypt, a new popular discourse, expressed in vernacular forms of language, in the media and in the writings of intellectuals and political analysts, stresses the support of "Egyptian women" as a uniform category, for the Egyptian military in their war against Islamist terrorism. The portrayal of Egyptian women's universal infatuation with the military General-turned-President overlooks the diversity of reasons for which many women supported the military overthrow of the Brotherhood. It also overlooks the intentional ways in which the idea of universal support was manufactured for political reasons. While the ruling military regime did actively promote this image and encourage its circulation in the media, it is also the result of the self-promoting efforts of certain statist female figures, both in the government and outside it, who simply saw

25. For examples of this particular discourse, see this video of women explaining why they are demonstrating against the Muslim Brotherhood's constitution, see: https:// www.youtube.com/watch? $v=$ dqQrOIF-y_Y. 
themselves as representative of certain interests that would have been hurt, had the Muslim Brotherhood continued to rule.

One source of the manufacturing this image of Egyptian women as one unified group might be found in the attempts by notable state feminists to revive a legacy of state feminism that had undergone serious questioning following the January 25th, 2011 revolution. In this sense, El-Sissi's women as an ideological construction, might reflect these state feminists' bid to regain a position that they have lost. Another reason might lie in the increasing challenge that the state faces in combating sexual violence in the public sphere, a challenge that the state institutions have failed to meet in any successful way so far. Promoting El-Sissi as the great savior of women might also serve to lessen public fears about a phenomenon that has seemed to be slipping out of control and that threatens women's presence in the public sphere. In addition, the emerging, diverse gender discourses that stress women's support for the new military state as unanimous and uncontested, might also be motivated by an attempt to erase a rich three-year history of independent gender-based mobilization, especially around the issue of gender violence in the public sphere. Although independent mobilization attempts were weakened in the period following June 30th, 2013, they have nevertheless managed to challenge deep-seated patriarchal notions on women's roles in public space. Independent activists, groups and organizations greatly troubled those notions by introducing the concept of "body politics" to mainstream national discourses on women. Furthermore, such activism has resulted in significant changes in the national discourse on sexual violence, prompting for the first time, official state recognition of the extent of this problem.

Thus, understanding the phenomena of El-Sissi's women requires in turn, an understanding of the challenges that state feminist projects in Egypt have faced over the past four years. Ironically, El-Sissi's women, as subjects and as ideological and politically-motivated constructions, might be the product of a backlash against women by all parties and at the same time, a result of the revival in gender discourse in Egypt after 2011. It remains to be seen, however, whether any of the emerging discourses on women in Egypt can free itself from the trappings of identity politics that have impeded the possibilities of independent mobilization for a long time, as well as the emergence of a political discourse on women's rights that is grounded in the reality of women's experiences, and not in their supposed political or cultural identities. Could such an understanding of women's rights emerge in Egypt, given the latest political developments? As Egypt's ruling military regime turns into an outright dictatorship with thousands arrested and jailed, separating women's rights from politics at large is becoming more difficult. As independent women's voices become silenced, and the country sinks more into the grip of military dictatorship, Egyptian feminism seems to be sliding more and more into the trappings of an endless identity debate. This debate conceals state paternalism and its direct role in women's oppression by highlighting its 
protective role toward women, and by precluding the emergence of new forms of activism that could bridge the fault lines of identity and reclaim a space for the diverse experiences of women that have emerged over the past four years.

\section{BIBLIOGRAPHY}

\section{Books:}

Badran, Margot. 2009. Feminism in Islam: Secular and Religious Convergences. Oxford: Oneworld Publications.

Baron, Beth. 2005. Egypt As A Woman: Nationalism, Gender and Politics. Berkeley: University of California Press.

Bier, Laura. 2011. Revolutionary Womanhood: Feminisms, Modernity and the State in Nasser's Egypt. Stanford: Stanford University Press.

El-Shakry, Omnia. 2007. The Great Social Laboratory: Subjects of Knowledge in Colonial and Postcolonial Egypt. Stanford, CA: Stanford University Press.

Kholoussy, Hanan. 2010. For Better, For Worse: The Marriage Crisis That Made Modern Egypt. Stanford: Stanford University Press.

Mahmoud, Sabaa. 2004. Politics of Piety: The Islamic Revival and the Feminist Subject. Princeton: Princeton University Press.

Mitchell, Timothy. 1991. Colonizing Egypt. Berkeley: University of California Press.

Rofel, Lisa. 1999. Other Modernities: Gendered Yearnings in China After Socialism. Berkeley: University of California Press.

\section{Online Articles:}

Eric Cunningham", In Egypt, presidential contender Abdel Fatah al-Sissi appeals to women voters", Washington Post at: http://www.washingtonpost.com/ world/in-egypt-presidential-contender-abdel-fattah-al-sissi-appeals-towomen-voters/2014/05/25/eb880eb0-99cd-44d9-ac0e-98e077d2ff33_story. html. Accessed on 9/8/2014.

Sara Abdel Rahim, "Sissi, the candidate for Egyptian women? Tahrir Institute for Middle East Policy's at: http://timep.org/commentary/sisi-candidate-foregyptian-women. Accessed on 9/9/2014.

"Egypt's Sissi faces challenge over 'sexual terror', The Times of Israel: http:// www.timesofisrael.com/egypts-sisi-faces-challenge-over-sexual-terror. Accessed on 11/9/2014.

Patrick Kingsley " Seven arrested for sexually assaulting student during Tahrir Celebrations:" The Guardian at : http://www.theguardian.com/world/2014/ jun/09/seven-arrest-sexual-assault-student-tahrir-square-sisi-inauguration. Accessed on 9/8/2014. 
Mada Masr " Sissi visits Tahrir Square mob sexual assault victim in hospital at: http://www.madamasr.com/content/sisi-visits-tahrir-square-mob-sexual-assault-victim-hospital. Accessed on 15/9/2014.

Khafagy, Fatma. 8-14 March 2007. "Commentary: A look at the women's machinery". Al-Ahram Weekly online at: http://weekly.ahram.org.eg/2007/ 835/sc14.htm. Accessed on 20/9/2014.

Muslim Brotherhood statement on the UN declaration on violence against women, Ikwan online at: http://www.ikhwanweb.com/article.php?id=30731 Accessed on 9/9/2014.

CBC's report on January 8th 2013 at: http://www.cbc.ca/news/world/formertop-court-judge-challenges-egypt-s-new-constitution-1.1390698 Accessed on $9 / 8 / 2014$.

Dalia Rabie "Sisi and his women: The military candidate appeals to women without offering them much in return", Mada Masr at http://www.madamasr. com/content/sisi-and-his-women Accessed on 9/11/2014.

The United Commission of the Status of Women fifty seventh session, General Assembly Declaration at: http://www.un.org/womenwatch/daw/csw/csw57/ CSW57_Agreed_Conclusions_\%28CSW_report_excerpt\%29.pdf. Accessed on $9 / 8 / 2014$.

YouTube Videos:

https://www.youtube.com/watch?v=wlfVyq5Y_ek Accessed on 9/9/2014. https://www.youtube.com/watch?v=yEL8kz4EiUU Accessed on 9/9/2014. https://www.youtube.com/watch?v=gkM6C52gl-w Accessed on 9/10/2014. 